Vol.3, No.2, November 2017

p-ISSN: 2442-8884 / e-ISSN: 2541-4542

J-Kesmas

Jurnal Kesehatan Masyarakat

\title{
Hubungan Motivasi dengan Kinerja Kader Posyandu di Kecamatan Bulo Kabupaten Polewali Mandar
}

\author{
Hariani ${ }^{1}$ Ramlah,SKM ${ }^{2}$ \\ Kampus Universitas Al Asyariah Mandar, Fakultas Kesehatan Masyarakat. \\ Jl. Budi Utomo No.2 Manding, Kecamatan Polewali, Kabupaten Polewali Mandar, \\ Provinsi Sulawesi Barat, Indonesia. \\ E-mail: Haryani23@yahoo.com
}

\begin{abstract}
Abstrak
Posyandu akan meningkatkan kinerja kader Posyandu. Namun permasalahan yang terjadi adalah masih banyak kader yang kurang termotivasi dalam kegiatan Posyandu. Persentase kader aktif secara nasional adalah 69,2\% dan angka drop out kader sekitar $30,8 \%$. Tujuan penelitian ini adalah untuk mengetahui hubungan motivasi dengan kinerja kader Posyandu di Kecamatan Bulo. Jenis penelitian ini adalah penelitian kuantitatif dengan desain observasional (cross sectional). Populasi adalah seluruh kader Posyandu di Kecamatan Bulo sebanyak 53 kader dan sampel adalah total sampling sebanyak 53 kader. Variabel dalam penelitian ini adalah tanggung jawab, insentif, hubungan kerja dan prosedur kerja kader Posyandu. Instrument yang digunakan adalah kuesioner dan wawancara. Data dalam penelitian ini dianalisis dengan analisis univariat dan bivariate dengan menggunakan uji Chi-square dengan dengan $\alpha=0,05$. Dari hasil analisis bivariat ada variabel berhubungan dan tidak berhubungan dengan kinerja kader Posyandu. Berdasarkan tanggung jawab diperoleh $\mathrm{p}$ value $=1,000>\alpha=0,05$, insentif diperoleh $\mathrm{p}$ value $=0,005<\alpha=0,05$, hubungan kerja diperoleh $\mathrm{p}$ value $=0.005<\alpha=0,05$ dan prosedur kerja diperoleh $\mathrm{p}$ value $=$ $0,031<\alpha=0,05$. Disimpulkan bahwa tidak terdapat hubungan tanggung jawab dengan kinerja kader Posyandu dan terdapat hubungan insentif, hubungan kerja dan prosedur kerja dengan kinerja kader Posyandu. Posyandu yang ada didaerahnya karena Posyandu merupakan pelayanan dasar yang dapat mendeteksi penyakit balita serta ibu hamil secara cepat.
\end{abstract}

Kata Kunci: Motivasi, Kinerja Kader Posyandu 
Vol.3, No.2, November 2017

J-Kesmas

Jurnal Kesehatan Masyarakat

\section{PENDAHULUAN}

Pembangunan kesehatan merupakan bagian dari pembangunan nasional dalam rangka mewujudkan visi misi presiden dan implementasi Nawa Cita yang kelima yaitu meningkatkan kualitas hidup manusia. Untuk mewujudkan derajat kesehatan masyarakat yang setinggi-tingginya diselenggarakan upaya kesehatan perorangan dan upaya kesehatan masyarakat, dengan pendekatan promotif, preventif, kuratif, rehabilitative. Secara terpadu menyeluruh, dan berkesinambungan. (Moeloek Farid Nila. 2016)

Posyandu merupakan salah satu bentuk Upaya Kesehatan Bersumber Masyarakat (UKBM) yang dikelola dari, oleh, untuk dan bersama masyarakat, guna memberdayakan masyarakat dan memberikan kemudahan kepada masyarakat dalam memperoleh pelayanan kesehatan dasar. Upaya peningkatan peran dan fungsi Posyandu bukan semata-mata tanggung jawab pemerintah saja, namun semua komponen yang ada di masyarakat, termasuk kader. Peran kader dalam penyelenggaraan Posyandu sangat besar karena selain sebagai pemberi informasi kesehatan kepada masyarakat juga sebagai penggerak masyarakat untuk datang ke Posyandu dan melaksanakan perilaku hidup bersih dan sehat. (Nugraha Monica Xaveria, 2013)

Keberhasilan Posyandu salah satunya dipengaruhi oleh kinerja kader, dengan motivasi yang tinggi dalam kegiatan Posyandu akan meningkatkan kinerja kader Posyandu. Namun permasalahan yang terjadi adalah masih banyak kader yang kurang termotivasi dalam kegiatan Posyandu.

Kader Posyandu adalah anggota masyarakat yang dipilih dari dan oleh masyarakat, mau dan mampu bekerja bersama dalam berbagai kegiatan kemasyarakatan secara sukarela. Persentase kader aktif secara nasional adalah 69,2 \% dan angka drop out kader sekitar 30,8 \%. Kader drop out adalah mekanisme yang alamiah karena pekerjaan yang didasari 
sukarela tentu saja secara kesisteman tidak mempunyai ikatan yang kuat. Berbagai keterbatasan yang meliputi sumber daya, kemampuan dan keterampilan baik dari pihak puskesmas maupun para kader serta peran serta masyarakat merupakan hambatan pada kegiatan posyandu. Hal ini menunjukkan bahwa partisipasi kader dalam menjalankan kegiatan Posyandu masih kurang aktif dan tidak berjalan dengan baik. (Diviani Mera Gracetiara, 2015)

Dari hasil studi pendahuluan yang dilakukan tanggal 14 September 2016 didapatkan bahwa Puskesmas Bulo terdapat 23 Posyandu sedangkan yang aktif hanya 6 Posyandu dengan jumlah kader 53. Dari hasil wawancara dengan koordinator bidan Kecamatan Bulo tidak semua kader aktif datang pada saat pelaksanaan posyandu terkadang hanya 2 kader yang datang pada kegiatan Posyandu, sehingga meja 1 dan meja 2 digabung jadi satu dan dijalankan oleh seorang kader, hal ini karena keterbatasan kader disebabkan adanya kader drop out karena lebih tertarik ditempat lain yang memberikan keuntungan ekonomi serta kader juga sering mengurusi kesibukannya seperti mengurusi anak dan pergi ke acara pernikahan.

\section{BAHAN DAN METODE}

Jenis penelitian yang digunakan adalah penelitian kuantitatif dengan desain cross sectional yang mengkaji hubungan motivasi dengan kinerja kader Posyandu. Penelitian dilakukan pada tanggal 18-24 Desember 2017 di Kecamatan Bulo. Populasi dalam penelitian ini adalah seluruh kader Posyandu di Kecamatan Bulo yaitu sebanyak 53 kader. Sampel dalam penelitian adalah total sampling. Data dianalisis secara univariat yakni melihat tampilan distribusi frekuensi dan persentase dari tiap variabel, serta di analisis secara bivariat, untuk melihat hubungan antara variabel dengan menggunakan Uji Statistik yang akan digunakan Uji Chi-Square dengan tingkat kemaknaan $(\alpha)=0,05$. 


\section{HASIL}

\section{Gambaran Umum Lokasi Penelitian}

Kecamatan Bulo terletak di Kabupaten Polewali Mandar Sulewasi Barat, dan merupakan salah satu daerah yang struktur lokasi maupun wilayahnya berupa dataran tinggi atau pegunungan. Luas wilayah Kecamatan Bulo $\pm 229.15 \mathrm{KM}^{2}$, serta berjarak tempuh 50 KM dari Ibukota Kabupaten Polewali Mandar. Adapun Kecamatan Bulo terdiri dari 9 desa yaitu Kelurahan Bulo, Desa Pulliwa, Desa Ihing, Desa Karombang, Desa Sabura, Desa Sepporaki, Desa Daala Timur, Desa Batambanua, Desa Lenggo.

Batas-batas Kecamatan Bulo adalah sebangai barikut: Sebelah barat berbatasan dengan Kecamatan Tubbi Taramanu, Sebelah timur berbatasan dengan Kecamatan Matangnga, Sebelah utara berbatasan dengan Kecamatan Mambi Kabupaten Mamasa, Sebelah selatan berbatasan dengan Kecamatan Mapilli.

\section{Karakteristik Umum Responden}

\section{a. Jenis Kelamin}

\section{Gambar 1 Distribusi Responden}

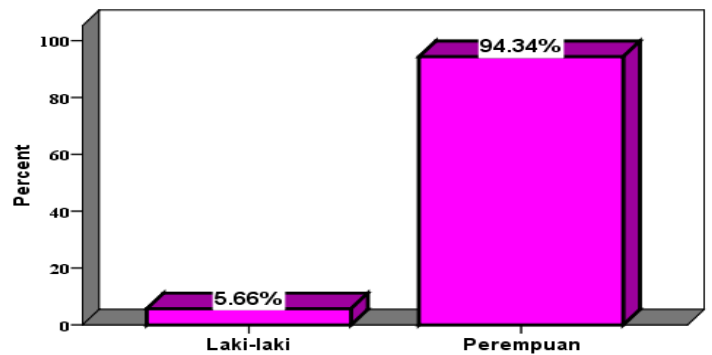

Sumber data: Primer,2016

Berdasarkan gambar karakteristik responden menurut jenis kelamin menunjukkan bahwa perempuan lebih banyak yaitu sebanyak 50 kader $(94.34 \%)$ sedangkan laki-laki sebanyak 3 kader $(5.66 \%)$.

b. Umur

\section{Gambar 2 Distribusi Responden}

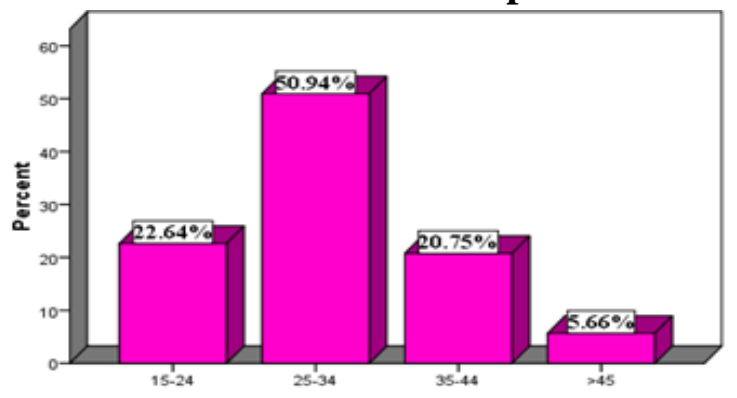

Sumber data: Primer,2016

Sedangkan proporsi umur responden berdasarkan gambar menunjukkan bahwa yang paling banyak yaitu umur 25-34 tahun sebanyak 27 kader $(50.94 \%)$ 
Vol.3, No.2, November 2017

J-Kesmas

Jurnal Kesehatan Masyarakat

sedangkan umur yang paling sedikit yaitu umur $>45$ tahun yaitu 3 kader $(5.66 \%)$.

\section{c. Pendidikan}

Gambar 3 Distribusi Responden Menurut Pendidikan

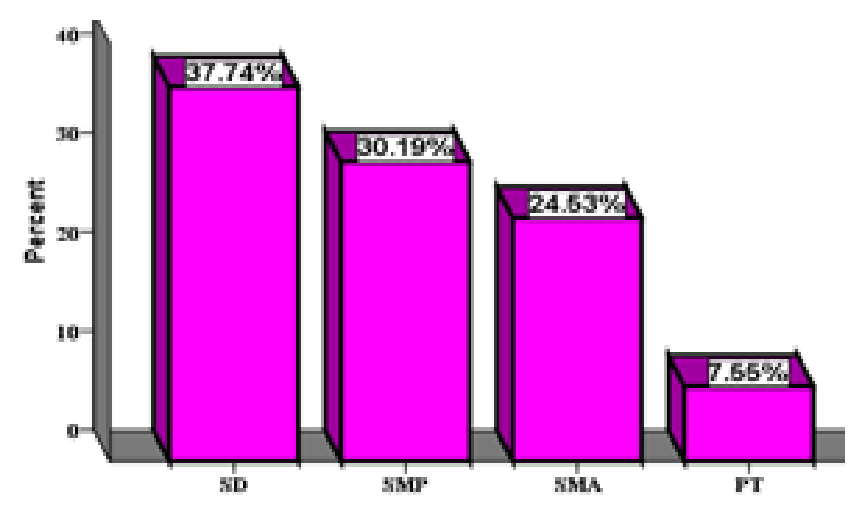

Sumber data: Primer, 2016

Berdasarkan gambar proporsi pendidikan responden yang paling banyak yaitu SD sebanyak 20 kader (37.74\%) sedangkan yang paling sedikit yaitu PT sebanyak 4 kader $(7.55 \%)$.

\section{Variabel yang diteliti}

Berdasarkan penelitian diperoleh data hasil kuesioner responden tentang skor tanggung jawab dengan kategori baik sebanyak 38 kader $(71,1 \%)$ dan tanggung jawab kategori kurang baik sebanyak 15 kader (28,3\%). Sedangkan variabel insentif diperoleh hasil bahwa responden yang puas dengan insentif yang diberikan sebanyak 30 kader $(56,6 \%)$ sedang yang kurang puas dengan insentif yang diberikan sebanyak 23 kader (43.3\%). Variabel hubungan kerja diperoleh hasil bahwa responden dengan hubungan kerja yang baik sebanyak 35 kader (66.0\%) sedangkan responden yang hubungan kerja kurang baik sebanyak 18 kader (34.4\%) dan untuk variabel prosedur kerja diperoleh hasil bahwa responden yang mengatakan prosedur kerja baik sebanyak 30 kader $(56.6 \%)$ sedangkan yang mengatakan prosedur kerja kurang sebanyak 23 kader (34.4\%). 
Vol.3, No.2, November 2017

J-Kesmas

Jurnal Kesehatan Masyarakat

Uji Statistik

1. Hubungan tanggung jawab dengan kinerja kader Posyandu

Tabel 1: Hubungan Tanggung Jawab Dengan Kinerja Kader Posyandu

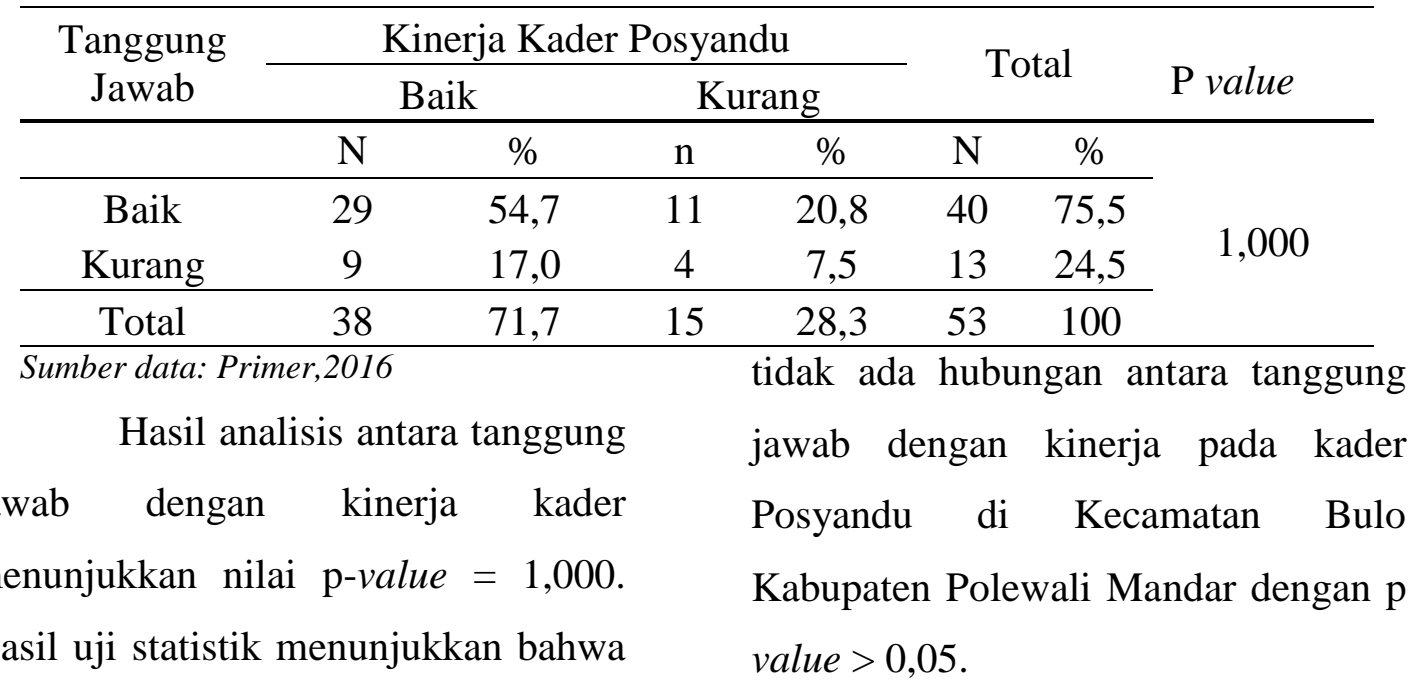

2. Hubungan insentif dengan kinerja kader Posyandu

Tabel 2: Hubungan Insentif Dengan Kinerja Kader Posyandu

\begin{tabular}{ccccccccc}
\hline \multirow{2}{*}{ Insentif } & \multicolumn{3}{c}{ Kinerja Kader Posyandu } & \multicolumn{2}{c}{ Total } & \multirow{2}{*}{ P value } \\
\cline { 2 - 6 } & \multicolumn{2}{c}{ Baik } & \multicolumn{2}{c}{ Kurang } & & & \\
\cline { 2 - 7 } & $\mathrm{n}$ & $\%$ & $\mathrm{n}$ & $\%$ & $\mathrm{~N}$ & $\%$ & \\
\hline Puas & 27 & 50,9 & 13 & 24,5 & 40 & 75,5 & \multirow{2}{*}{0,005} \\
Kurang Puas & 3 & 5,7 & 10 & 18,9 & 13 & 24,5 & \\
\hline Total & 30 & 56,6 & 23 & 43,4 & 53 & 100 & \\
\hline Sumber data: Primer 2016 & & & & & & &
\end{tabular}

Sumber data: Primer,2016

Hasil analisis antara insentif antara insentif dengan kinerja pada dengan kinerja kader menunjukkan kader Posyandu di Kecamatan Bulo nilai p-value $=0,005$. Hasil uji statistik Kabupaten Polewali Mandar dengan $\mathrm{p}$ menunjukkan bahwa ada hubungan value $<0,05$.

3. Hubungan antara hubungan kerja dengan kinerja kader Posyandu

Tabel 3: Hubungan antara Hubungan Kerja Dengan Kinerja Kader Posyandu

\begin{tabular}{lcccc}
\hline \multirow{2}{*}{ Hubungan Kerja } & \multicolumn{2}{c}{ Kinerja Kader Posyandu } & Total & P value \\
\cline { 2 - 3 } & Baik & Kurang & & Pall
\end{tabular}


Vol.3, No.2, November 2017

J-Kesmas

Jurnal Kesehatan Masyarakat

\begin{tabular}{|c|c|c|c|c|c|c|c|}
\hline & $\mathrm{N}$ & $\%$ & $\mathrm{n}$ & $\%$ & $\mathrm{~N}$ & $\%$ & \multirow{4}{*}{0,005} \\
\hline Baik & 31 & 58,5 & 9 & 17,0 & 40 & 75,5 & \\
\hline Kurang & 4 & 7,5 & 9 & 17.0 & 13 & 24,5 & \\
\hline Total & 35 & 66,0 & 18 & 34,0 & 53 & 100 & \\
\hline
\end{tabular}

Sumber data: Primer,2016

Hasil analisis antara ada hubungan antara hubungan kerja hubungan kerja dengan kinerja kader menunjukkan nilai $\mathrm{p}$-value $=0,005$. dengan kinerja pada kader Posyandu di Hasil uji statistik menunjukkan bahwa Kecamatan Bulo Kabupaten Polewali Mandar dengan $\mathrm{p}$ value $<0,05$.

4. Hubungan prosedur kerja dengan kinerja kader Posyandu

Tabel 4: Hubungan Prosedur Kerja Dengan Kinerja Kader Posyandu

\begin{tabular}{ccccccccc}
\hline \multirow{2}{*}{ Prosedur Kerja } & \multicolumn{4}{c}{ Kinerja Kader Posyandu } & \multirow{2}{*}{ Total } & \multirow{2}{*}{ P value } \\
\cline { 2 - 6 } & \multicolumn{3}{c}{ Baik } & \multicolumn{2}{c}{ Kurang } & & & \\
\cline { 2 - 7 } & $\mathrm{N}$ & $\%$ & $\mathrm{n}$ & $\%$ & $\mathrm{~N}$ & $\%$ & \\
\hline Baik & 26 & 49,1 & 14 & 26,4 & 40 & 75,5 & \multirow{2}{*}{0,031} \\
Kurang & 4 & 7,5 & 9 & 17,0 & 13 & 24,5 & \\
\hline Total & 30 & 56,6 & 23 & 43,4 & 53 & 100 & \\
\hline
\end{tabular}

Sumber data: Primer,2016

Hasil analisis antara prosedur kerja dengan kinerja kader menunjukkan nilai p-value $=0,031$. Hasil uji statistik menunjukkan bahwa

\section{PEMBAHASAN}

\section{A. Tanggung Jawab}

Dari hasil penelitian menunjukkan bahwa tidak ada hubungan tanggung jawab dengan kinerja kader Posyandu disebabkan karena tanggung jawab yang mendukung kinerja kader Posyandu di Kecamatan Bulo Kabupaten Polewali ada hubungan antara prosedur kerja dengan kinerja pada kader Posyandu di Kecamatan Bulo Kabupaten Polewali Mandar dengan p value $<0,05$.

Mandar masih jauh dari harapan hal ini terjadi akibat masih adanya beberapa Posyandu yang masih sulit di akses alat transportasi kendaraan roda dua maupun roda empat karena daerah yang tergolong masih sangat terpencil serta kader yang kurang pengawasan, 
J-Kesmas

Jurnal Kesehatan Masyarakat

dalam melaksanakan tugasnya terkadang kurang memperhatikan sebagaimana mestinya, seperti pelaksanaan pelayanan Posyandu terkadang tidak sesuai prosedur dan dalam mengerjakan pelayanan Posyandu tidak sesuai dengan jadwal yang telah ditetapkan.

Seorang kader Posyandu dalam sebuah institusi mempunyai hak dan kewajiban yang harus dilaksanakan yang keduanya merupakan mata rantai yang saling berkaitan. Hak merupakan berkaitan dengan apa yang menjadi miliknya setelah mereka melaksanakan kewajiban, sedangkan kewajiban bersifat apa yang harus dikerjakan. Dengan demikian seorang kader Posyandu mempunyai hak untuk mendapatkan penghasilan sesuai dengan peraturan yang berlaku, sedangkan kewajibannya adalah melaksanakan pekerjaan sesuai dengan tupoksinya dengan penuh tanggung jawab. Dengan demikian, tanggung jawab yang dimaksudkan disini adalah berkaitan erat dengan kewajiban seorang pegawai dalam melaksanakan pekerjaan secara sungguh-sungguh secara konsekuen yang diberikan oleh seseorang/institusi. ${ }^{1}$

Penelitian ini sejalan dengan penelitian yang dilakukan oleh Suwardi dan Amin Wahyudi tahun 2010, dimana bahwa tanggung jawab tidak berpengaruh secara signifikan terhadap kinerja Pegawai UPT Dinas Pendidikan Kecamatan Polokarto Kabupaten Sukoharjo. Berdasarkan hasil analisis regresi linear berganda, terlihat bahwa besarnya nilai t-hitung untuk tanggung jawab adalah 1,459, sedangkan besarnya t-tabel adalah 2,025. Ini berarti t-hitung lebih kecil dari t-tabel sehingga $\mathrm{H} 0$ diterima dan Ha ditolak. ${ }^{2}$

\section{B. Insentif}

Insentif adalah suatu bentuk motivasi yang dinyatakan dalam bentuk uang atas dasar kinerja yang tinggi dan juga merupakan rasa pengakuan dari pihak organisasi terhadap kinerja karyawan dan kontribusi terhadap organisasi. ${ }^{3}$

Berdasarkan hasil penelitian yang dilakukan di Kecamatan Bulo 
Kabupaten Polewali Mandar tentang insentif seorang kader Posyandu, menunjukkan bahwa ada hubungan antara insentif dengan kinerja kader Posyandu. Data membuktikan bahwa dengan adanya insentif, umumnya kader lebih termotivasi untuk menyelesaikan tugas-tugasnya dibandingkan bila kader tidak memperoleh insentif. Dengan demikian, insentif merupakan salah satu faktor pendorong kader dalam bekerja.

Sistem pemberian insentif menimbulkan rasa ketidakpuasan dalam diri kader. Kader merasa diperlakukan kurang adil dengan sistem pemberian jumlah insentif tidak mengarah pada beban kerja yang ada. Kader yang rajin datang ke Posyandu dengan kader yang jarang datang ke Posyandu, kader yang beban kerjanya yang tinggi dengan kader yang beban kerjanya kurang, menerima insentif yang sama.

Di sisi lain, keluhan kader muncul berkenaan dengan jumlah insentif dan keterlambatan waktu pembayaran serta berdasarkan penelitian bahwa kader kurang memprioritaskan pekerjaan di Posyandu dengan ditemui 52 kader lebih memilih mencari pekerjaan lain untuk mendapatkan insentif kemudian ada 11 kader yang drop out karena lebih memilih pekerjaan yang insentifnya memuaskan.

Insentif sangat mempengaruhi kinerja kader karena meningkatkan semangat kader dan menjadi bukti pembinaan dari puskesmas. Pemberian insentif tersebut berpengaruh positif. Para kader bertugas tidak hanya ketika penimbangan posyandu, tetapi juga sebelum dan sesudahnya. Kader juga melakukan pendataan di masyarakat dan menjadi agen penyebar informasi beberapa program pemerintah seperti pertanian dan KB. Proyek yang berhasil umumnya menggunakan beberapa insentif secara simultan untuk memotivasi kader kesehatan masyarakat. Dukungan tokoh masyarakat sangat penting dan menentukan keberhasilan serta kesinambungan kegiatan posyandu.

Hal ini sejalan dengan penelitian yang dilakukan oleh Muh. 
Haiyi yaitu berdasarkan uji parsial ada pengaruh yang signifikan pemberian insentif terhadap kinerja kader gizi di Posyandu Mandiri di Kota/Kabupaten Blitar dengan $(\mathrm{P}=0,025){ }^{4}$

\section{Hubungan Kerja}

Hubungan kerja dapat diartikan sebagai hubungan yang terjadi antara bagian- bagian atau individu-individu baik antara mereka di dalam organisasi maupun antara mereka dengan pihak luar organisasi sebagai akibat penyelenggaraan tugas dan fungsi masing- masing dalam mencapai sasaran dan tujuan organisasi (Siwi Ultima Kadarmo dkk, 2001: 10). Untuk dapat melaksanakan pekerjaan dengan baik, haruslah didukung oleh suasana atau hubungan kerja yang harmonis antara sesama pegawai maupun atasan dan bawahan. Namun keharmonisan dalam hubungan kerja diperlukan kekompakan antara kader serta instansi yang terkait dengan hal ini dapat meningkatkan motivasi kerja masing-masing pihak. ${ }^{5}$

Pada umumnya, hubungan kerja yang kurang baik akan mempengaruhi kinerja. Padahal hal ini dapat menyebabkan organisasi tidak berjalan dengan lancar dalam mencapai misi maupun visi yang telah direncanakan. Sehingga dibutuhkan kesadaran masing-masing pihak.

Dari hasil penelitian, dapat dibuktikan bahwa di Kecamatan Bulo, hubungan kerja berhubungan kuat dengan kinerja kader Posyandu, yang dimana terjadi kekompakan antara sesama kader dalam mengerjakan tugas-tugas dalam kegiatan Posyandu, terjalin hubungan baik pegawai Puskesmas dan aparat desa dengan seorang kader, serta dengan pembuatan catatan kegiatan Posyandu yang dilakukan secara rutin menyebabkan hubungan antara sesame kader semakin baik.

Penelitian ini sejalan dengan penelitian yang dilakukan oleh Ernawati (2010). Hasil penelitian ini diperoleh bahwa hubungan kerja mempunyai pengaruh signifikan terhadap kinerja pegawai Badan Kepegawaian Daerah Kabupaten Karanganyar hal ini dibuktikan dengan 
besarnya probability value $0,000<$ $0,05{ }^{6}$

\section{Prosedur Kerja}

Dalam bekerja kader harus dapat menguasai tugas dan mampunyai kemampuan menyelesaikan tugas yang didasarkan atas prosedur yang telah ditetapkan sehingga penting bagi kader untuk mengerti dan memahami dan menjadikan prosedur kerja sebagai pedoman dalam bekerja. Prosedur berperan penting dalam memberikan acuan terkait dengan kegiatankegiatan yang dijalankan dalam organisasi agar berjalan efektif, sehingga membantu organisasi untuk mencapai tujuannya, baik yang bersifat jangka pendek maupun yang jangka panjang.

Manfaat prosedur sebagai pedoman kegiatan adalah menjadi pedoman kegiatan-kegiatan organisasi, baik secara operasional maupun administratif. Sebagai pedoman kegiatan, prosedur kerja harus berperan mengurangi pengulangan kerja (reworks) yang tidak perlu, karena pengulangan kerja adalah bentuk lain dari ketidakefektifan prosedur kerja. Sebagai pedoman prosedur kerja harus berjalan efektif dan efisien sesuai dengan kebutuhan organisasi dan dalam kondisi apapun. Dengan demikian prosedur kerja dapat menjadi pedoman penilaian kinerja pegawai maksudnya dengan diterapkannya prosedur kerja yang jelas akan membawa kemudahan bagi organisasi untuk melakukan review dan penilaian kinerja, dan prosedur kerja dapat membangun kondisi dan situasi kerja yang lebih baik bagi karyawan yang akan berakibat pada kinerja karyawan yang baik. ${ }^{6}$

Dari hasil penelitian, dapat dibuktikan bahwa ada hubungan yang signifikan antara prosedur kerja dengan kinerja kader Posyandu di Kecamatan Bulo Kabupaten Polewali Mandar. Hal ini disebabkan karena prosedur kerja yang telah ditetapkan sudah diikuti oleh sebagian kader seperti pelaksanaan pelayanan Posyandu disesuaikan dengan prosedur pelayanan yaitu mulai dari tahap pendaftaran hingga tahap pelayanan, prosedur pelayanan Posyandu yang 
sesuai dengan tupoksi seorang kader, kader dalam memberikan pelayanan Posyandu tetap memperhatikan kondisi kesehatan ibu dan anak yang sesuai dengan prosedur kerja serta kader tetap menyesuaikan perkembangan kondisi kesehatan ibu dan anak ketika melaksnakan pelayanan Posyandu.

Penelitian ini sejalan dengan penelitian yang dilakukan oleh Ratih Nugraheni, Apriatni EP dan Agung Budiatmo (2013). Berdasarkan hasil tabel silang antara posedur kerja dengan kinerja kader Posyandu diketahui bahwa prosedur kerja yang baik akan berpengaruh baik terhadap kinerja kader pramuniaga Pasaraya Sriratu Semarang sebesar 50,8\%. Dengan demikian terdapat kecenderungan hubungan yang positif antara prosedur kerja dengan kinerja pramuniaga. Berdasarkan uji $\mathrm{t}$ yang dilakukan terhadap variabel prosedur kerja dan pengaruhnya terhadap variabel kinerja diketahui bahwa nilai $\mathrm{t}$ hitung $(13,280)>\mathrm{t}$ tabel $(1,9990)$ sehingga ada pengaruh antara prosedur kerja dengan kinerja pramuniaga. ${ }^{7}$

\section{KESIMPULAN}

Berdasarkan hasil penelitian yang dilakukan di Kecamatan Bulo Kabupaten Polewali Mandar, dapat disimpulkan bahwa:

1. Tidak ada hubungan tanggung jawab dengan kinerja kader Posyandu di Kecamatan Bulo Kabupaten Polewali Mandar dengan nilai $(\mathrm{p}$ value $)=1,000>\alpha=$ 0,05

2. Ada hubungan insentif dengan kinerja kader Posyandu di Kecamatan Bulo dengan nilai (p value $)=0,005<\alpha=0,05$.

3. Ada hubungan antara hubungan kerja dengan kinerja kader Posyandu di Kecamatan Bulo dengan nilai $(\mathrm{p}$ value $)=0,005<\alpha=$ 0,05 .

4. Ada hubungan prosedur kerja dengan kinerja kader Posyandu di Kecamatan Bulo dengan nilai (p value $)=0.031<\alpha=0,05$.

\section{SARAN}

Pemerintah sebaiknya lebih meningkatkatkan pengawasan terhadap kinerja kader dan mengetahui 
Vol.3, No.2, November 2017

p-ISSN: 2442-8884 / e-ISSN: 2541-4542

J-Kesmas

Jurnal Kesehatan Masyarakat

penyebab kekurang aktifan seorang dan mengikuti prosedur yang telah

kader Posyandu agar permasalahan ditetapkan sehingga program

mengenai kesehatan ibu dan anak tetap Posyandu tetap terlaksana dengan

teratasi secara efektif dan efesien. baik.

menjalin hubungan kerja yang baik

\section{DAFTAR PUSTAKA}

Moeloek Farid Nila. 2016. Profil Kesehatan 2015. Jakarta

Nugraha Monica Xaveria. Hubungan antara Tanggung Jawab, Kepuasan Kerja dan Motivasi Kerja dengan Kinerja Karyawan. Fakultas Ekonomi Universitas Sanata Dharma Yogyakarta, 2013.

Suwardi, Wahyudi Amin. Pengaruh Komunikasi, Kedisiplinan, Dan Tanggung Jawab Terhadap Kinerja Pegawai Di Upt Dinas Pendidikan Polokarto Sukoharjo. Fakultas Ekonomi Universitas Slamet Riyadi Surakarta, 2010

Diviani Mera Gracetiara. Analisis Pengaruh Insentif terhadap Kinerja Karyawan dengan Kepuasan Kerja sebagai Variabel Mediasi. Fakultas Ekonomi dan Bisnis Universitas Diponegoro, 2015.

Muh. Haiyi. Pengaruh Pemberian Insentif Pada Kader Gizi Terhadap Kinerja Dan Kepuasan Pengguna Posyandu Mandiri Di Kota/Kabupaten Blitar. Universitas Sebelas Maret Surakarta, 2015.

Ernawati. Pengaruh Hubungan Kerja dan Lingkungan Kerja terhadap Kinerja Pegawai dengan Motivasi Kerja sebagai Variabel Moderating. Fakultas Ekonomi Universitas Slamet Riyadi Surakarta, 2010

Nugraheni Ratih, dkk. Pengaruh Standar Operasional Prosedur dan Pengawasan terhadap Kinerja Pramuniaga Pasaraya Sriratu Pemuda Semarang. Fakultas Ilmu Sosial dan Ilmu Politik. Universitas Diponegoro, 2014. 